УДК [94 : 329] (477) «1920/1925»

DOI: https://doi.org/10.33782/eminak2019.2(26).293

\title{
ЗАКОНОДАВЧА РЕГЛАМЕНТАЦІЯ ТА МЕХАНІЗМИ КОНТРОЛЮ БІЛЬШОВИЦЬКОЇ ВЛАДИ ЗА ДІЯЛЬНІСТЮ ГРОМАДСЬКИХ ОБ'ЄДНАНЬ УКРАЇНИ У ПЕРШІЙ ПОЛОВИНІ 1920-Х РОКІВ
}

\author{
Ігор Ніколаєв \\ Миколаївський національний університет ім. В.О. Сухомлинського (Миколаїв, Україна) \\ e-mail: igornikkolaev@gmail.com \\ ORCID: https://orcid.org/0000-0003-3001-9717
}

\begin{abstract}
У публікації, на основі широкої історіографічної та джерельної бази, проаналізовано ключові чинники встановлення більшовицької монополії у суспільно-громадській площині. Показано механізми правової регламентації позадержавного суспільного простору. Доведено, що основною метою встановлених законодавчих норм у сфері функціонування громадських об'єднань було здійснення правлячим режимом контролю за їх діяльністю, залучення їх представників до формування радянського державного апарату.
\end{abstract}

Ключові слова: громадські об'єднання, тоталітарна система, радянська влада, законодавство, УСРР

Розвиток конституційного процесу в сучасній Україні передбачає вирішення комплексу проблем, пов'язаних із забезпеченням конституційного принципу політичного різноманіття й створення умов для повноцінної реалізації політичних прав громадян, актуалізує перед дослідниками цілий комплекс наукових напрямів. Одним з них є дослідження змісту, особливостей і тенденцій правового регулювання питань, пов'язаних з формуванням і діяльністю громадських об'єднань та організацій. Історико-правова оцінка діяльності громадських інституцій у конкретних історичних умовах дозволяє виявити ефективність практичної реалізації радянських правових механізмів, спрямованих на концентрацію влади у руках однієї політичної сили та тотального контролю влади над усіма сферами суспільно-політичного, економічного та приватного життя. Враховуючи це, не викликає сумнівів актуальність вивчення тематики становлення тоталітарного суспільства 3 диктатурою однієї партії у 1920-х роках.

Означена проблема протягом тривалого часу привертала увагу вітчизняних і закордонних дослідників. Відзначимо роботу професора, доктора права Мюнхенського Українського вільного університету А.Білинського, присвячену становищу та розвитку громадських організацій СРСР. Вчений дає юридичну оцінку постановам радянських урядів, як українських, так і загальносоюзних, щодо громадських об'єднань ${ }^{1}$. Серед чисельних праць вітчизняних дослідників слід виділити роботу С. Кульчицького, присвячену комплексному аналізу розвитку УСРР у перше більшовицьке десятиріччя² . До проблеми репресивних методів становлення монополії більшовизму звертається у своїй монографії В. Ченцов 3 .

\footnotetext{
${ }^{1}$ Білинський А.К. Громадські організації в СРСР. Мюнхен-Чікаго: Український публіцистичнонауковий інститут, 1969. 160 с.

2 Кульчицький С.В. Комунізм в Україні: перше десятиріччя (1919-1928рр.). Київ: Основи, 1996. 396 c.

3 Ченцов В.В. Політичні репресії в Радянській Україні в 20-ті роки. Тернопіль: Збруч, 2000. 481 с.
} 
Втім, незважаючи на наявність значної кількості опублікованих праць, в українській історіографії існує потреба комплексного дослідження становлення гегемонії більшовицької влади, вивчення різноманітних аспектів проблематики.

Революційна розбудова «найсправедливішої» держави та якісно нового суспільства, у баченні більшовиків, передбачала встановлення монополії не тільки у площині політичних партій, а й у системі функціонування громадсько-політичних об’єднань. Ідея історичної невідворотності та безальтернативності «класової боротьби» визначила концепцію використання громадських об'єднань для забезпечення, підготовки та досягнення революційних завдань. Всі непідконтрольні владі організації сприймалися як інструмент реваншу буржуазї, а відтак прирікалися на знищення у процесі соціалістичних трансформацій. Об'єднання дрібнобуржуазних сил розглядалися винятково з можливості їх використання як союзників у боротьбі з великою буржуазією та контрреволюцією.

Зазначимо, що у світовій нормативно-правовій практиці спектр позадержавних інститутів визначений достатньо чітко. Головні його складові - економічні та позаекономічні (некомерційні організації). При цьому структура некомерційних організацій включає: політичні об'єднання (партії), конфесійні організації (церква, релігійні товариства), професійні спілки, молодіжні, творчі, національні, спортивні й інші об'єднання ${ }^{4}$.

У радянській Україні позадержавний простір також поділявся на економічні та позаекономічні сфери. У період НЕПу на нетривалий час завдяки громадській ініціативі сформувалася недержавна сфера, до якої входили як економічні організації (спілки підприємців, орендаторів, кооперативні товариства), так і позаекономічні (профспілки, комсомол і товариства, які «не переслідували мету отримання прибутку»). Разом з тим навіть у відносно ліберальні часи першої половини 1920-х років 3 легального поля існування витіснялись релігійні організації й об’єднання, засновані на базі альтернативних правлячій партії.

На другу половину 1920-х років припиняють діяльність позадержавні економічні структури, внаслідок чого суспільна діяльність в Україні нівелюється до повністю підконтрольних владі профспілок, добровільних товариств, спортивних, міжнародних організацій. Саме ця мережа має право трактуватися як система «громадських об’єднань» у досліджуваний період становлення тоталітарної системи.

Центральною умовою для створення та діяльності громадських організацій у рамках легального правового поля виступала повна лояльність до радянської влади та її підконтрольність. Показовим є факт, що практично всі законодавчо-правові норми, серед них і пов'язані з регламентацією діяльності громадських об'єднань УСРР, базуватимуться на базі рішень центральних органів радянської влади, спочатку Російської Федерації, потім СРСР. Автоматичне впровадження загальноросійських норм на українське законодавство було традиційним явищем. Тим самим юридично закріплялась монополія правлячої загальноросійської комуністичної партії в усіх сферах життя інших республік та інтеграція суспільно-політичних організацій безпосередньо у систему радянської державної влади. Відбулось перетворення останніх у засіб втілення тоталітарної диктатури на всій території новоствореного Радянського Союзу за визначеним і встановленим однією партією шаблонам.

\footnotetext{
${ }^{4}$ Ильина И.Н. Общественные организации России в 1920-е годы / Отв. ред. А.К. Соколов. Москва: Ин-т рос. истории РАН, 2000. С. 34.
} 
На початку 1920 р., коли вирішувалася доля багатьох дореволюційних товариств і союзів, а також створювалися нові громадські організації, виникла необхідність у розробці документів для регламентації їх публічної діяльності. ВУНК, виконуючи відповідне розпорядження чекістського керівництва РСФРР, у червні 1920 р. зобов'язує всі губернські відділи видати постанови про обов'язкову реєстрацію релігійних груп, громад, об’єднань, направляючи звітні відомості до центрального наркомату до Москви. Саме там, за аналогією з радянською Росією, вирішувалась їх відповідність до норм соціалістичного законодавства та можливий «антирадянський характер» діяльності. Так, за даними губНК Київщини за січень-березень 1921 р. відмовлено у реєстрації 41 товариству (серед них 16 релігійних груп) 5 .

Також з початку 1920-х років зі зростанням кількості громадських організацій перед владою постала потреба не тільки законодавчого регламентування їх діяльності, а й контролю, одним з чинників якого виступало питання створення спеціального органу для реєстрації товариств і союзів. Унаслідок проведених заходів на середину 1920-х років в Українській СРР сформувався характерний державноправовий режим регламентації діяльності різного роду громадських об'єднань. Здійснення нагляду та контролю за організаційними формами вияву громадської ініціативи в Україні покладалося на різні органи державної влади. Серед них відділ національних меншин НКВС України, Центральна міжвідомча комісія у справах союзів і громад, що входила до складу адміністративно-організаційного управління НКВС, ДПУ, Наркомюст, Всеукраїнську надзвичайну комісію по боротьбі з контрреволюцією (ВУНК), Центральну комісію національних меншин при ВУЦВК та Головкооперком при РНК УСРР. Вказані установи протягом 1920-х років регламентували діяльність громадських організацій, що діяли у регіональному масштабі. Питаннями регулювання роботи окремих категорій організацій цього періоду займалися також ВЦВК і РНК РСФРР. Видані ними декрети визначали положення, порядок створення та діяльності кооперації, Товариства Червоного Хреста, науково-технічних організацій та інших організаційб.

Зазначимо, що в УСРР, як і в РСФРР, термін «громадські організації» використовувався у досить широкому змісті. Він застосовувався до об'єднань всілякого масштабу, характеру та напрямку діяльності. Документи 1920-х років підкреслюють термінологічне різноманіття юридичного позначення громадських об'єднань. У перших декретах ВЦВК і РНК мова йшла про «товариства» і «союзи». Поряд з ними одночасно використовувалися назви: «вільні гуртки», «масові організації», «добровільні товариства» й інші7.

У 1922 р. розпочато розробку головного законопроекту про товариства й союзи. Документ, який став основним регулюючим актом для громадських організацій на наступні шість років, ухвалено 3 серпня 1922 р. Постановою ВЦВК і РНК РСФРР «Про порядок затвердження й реєстрації організацій і спілок, що не переслідують отримання прибутку і про порядок нагляду за ними». У Постанові визначалось коло гро-

\footnotetext{
5 Галузевий державний архів Служби безпеки України (далі ГДА СБУ). Ф.13. Оп. 1. Спр. 193. Арк. 41-42.

${ }^{6}$ Степанчук Ю. Громадські організації України в системі радянської влади (1920-ті pp.) // II-й Міжнародний науковий конгрес українських істориків «Українська історична наука на сучасному етапі розвитку». Кам'янець-Подільський, 2003. С. 219.

7 Декреты Великого Октября [авторы-составители Ю. Ахапкин, М. Ирошников]. Ленинград: Лениздат, 1977. С. 25.
} 
мадських організацій, що належали до категорії добровільних, і режим їх діяльності на території усіх радянських республік.

Організації розподілялися за змістом (родом) діяльності, інтересами, правовим статусом (легальні та нелегальні), масовістю (складом членства), масштабами й сферою суспільного впливу й іншим. В Україні внаслідок цього виокремилось три основні групи об’єднань: 1. Організації підконтрольні партії (профспілки, комсомол, піонерська організація); 2. Українські організації та об'єднання національних меншин («Просвіти», УКРЮС, РСДРМ, релігійні католицькі гуртки, Євркомсомол, скаутські організації); 3. Добровільні товариства за інтересами, поява яких зумовлена внутрішніми та зовнішніми потребами функціонування радянської політичної системи певного періоду (товариство «Геть неписемність!», «Товариство культурного єднання з селом», «Спілка безвірників», «Друзі дітей», Міжнародна організація допомоги бійцям революції й інші). Окремим блоком виступала розгалужена мережа кооперації. На початку 1920-х років в Україні продовжували існувати національні об’єднання, зокрема: Спілка голландських вихідців, Менонітський союз, інші німецькі, єврейські, польські організації.

Головна умова діяльності всіх товариств зафіксована у пункті шостому Постанови: «В реєстрації відмовляється, якщо об’єднання або спілка за своїми цілями суперечить Конституції РСФРР і її законам»9. На підставі даної норми у вересні 1922 р. Одеський губком НКВС відмовив у реєстрації Товариству виноградарів-гагаузів Бессарабії, внаслідок його «Відверто вираженого антирадянського та поміщицького характеру...»10.

Дія Постанови від 3 серпня 1922 р. не поширювалась на релігійні товариства. Комісія, що проводила програму по відділенню церкви від держави при ЦК РКП(б) 21 листопада 1922 р. вирішила виключити релігійні організації із числа громадських об’єднань, що не мали за мету отримання прибутку, надавши їм окремого статусу.

Надалі становище релігійних об’єднань ускладнювалося курсом радянської влади на побудову атеїстичного суспільства. Плановий державний характер одержала антирелігійна й антицерковна пропаганда, що фактично призвело до витіснення релігійної діяльності з рамок правового поля. Численні звіти ДПУ УСРР вже з 1922 р. в цілому характеризують діяльність різноманітних церковних громад як «нелегальну, що підпільно проводять свої зібрання у приватних приміщеннях членів релігійних груп...»11.

Окрім релігійних громад, не дістали фактичного права на створення власних організацій і широкі прошарки селянства. При цьому сільські громадські організації функціонально орієнтувалися на вирішення не специфічно селянських, а інтернаціонально-революційних завдань. На думку дослідника етнонаціональних і міжнародних аспектів діяльності громадських об’єднань українського села 1920-30-х років М.Журби, провідним елементом утвердження ідеології пролетаріату у свідомості селянства визначалася його соціокультурна індоктринація. Лідери більшовицької партії, спираючись на теоретичну спадщину ортодоксального марксизму, інтегрували селянство в інтернаціональний революційний рух через посередництво про-

\footnotetext{
8 Ильина И.Н. Указ. раб. С. 39.

9 Там само. С. 44.

10 Державний архів Одеської області. Ф. П-7. Оп. 1. Спр. 2. Арк. 26-27.

11 ГДА СБУ. Ф. 13. Оп. 1. Спр. 193. Арк. 44.
} 
фесійних організацій і класових товариств ${ }^{12}$.

Сільські громадські об'єднання України поділялися на специфічно селянські і ті, що мали свої сільські представництва для виконання статутних завдань, які стосувалися переважно несільського населення. Ключові групи системи громадських об'єднань включали до свого складу добровільні та шефські товариства, професійні спілки, так звані класові селянські спілки з їх інфраструктурою, організації мережі невиробничої кооперації. При цьому в практиці залучення кооперації до неспецифічної інтернаціоналізації особливого значення набували селянські товариства взаємодопомоги (СТВ). Діяльність СТВ не обмежувалася соціальним забезпеченням найбідніших селянських прошарків, позаяк це не вирішувало проблем підтримки бідняцьких господарств. Вони зобов'язувались залучати найбідніше селянство до кооперативів як засобу консолідації незаможних і середняцьких верств села проти його власницьких елементів. Тим самим створювалась організаційна альтернатива самодіяльному селянському кооперативному рухові, який вкрай неохоче піддавався впливу правлячої еліти ${ }^{13}$.

Серйозну турботу влади викликали намагання політичних опонентів більшовиків, насамперед, з правоесерівського середовища, закріпити свої позиції серед найчисельнішої категорії населення. Так, циркулярний лист ВНК № 17 від 21 листопада 1921 р. до низових підрозділів присвячено намаганню правих есерів створити широке позапартійне об'єднання селянства «Союз трудового селянства». На думку чекістів, ця спроба $\epsilon$ намаганням створення куркульської партії, яка протиставляла себе пролетарській диктатурі й орієнтувалась на захист інтересів середніх і дрібних приватних власників земельних наділів. Ідеї та принципи «Союзу» суперечать економічній політиці радянської влади на селі, тому є неприпустимими ${ }^{14}$.

Відповідними до «революційної законності» стали дії каральних органів проти активістів «Союзу трудового селянства». У направленому плані заходів по ліквідації об'єднання, що складався з 15 пунктів, йшлося про смертельну загрозу куркульських об'єднань, пожвавлення агентурної роботи, виявлення зв'язків зі співчуваючим міським населенням. Дев'ятий пункт циркулярного розпорядження вимагав від місцевих органів ВНК широко застосовувати захоплення заручників: «При арештах керівників та організаторів Союзу негайно їх ізолювати. Успіх принесла практика, апробована в Україні та Тамбовській губернії зі взяття заручників з числа членів куркульських родин... При конфіскації та розподіленні їх майна особливу увагу звертати на посилення таким шляхом розшарування на селі та матеріальне заохочення осіб, які сприяють встановленню радянської влади» ${ }^{15}$.

Суперечки та розбіжності у правовому тлумаченні регламентації діяльності як для радянських органів влади, так і для самих товариств, викликали групи організацій допомоги та взаємодопомоги. Особлива актуалізація цього питання припала на початок 1920-х років, чому спонукало наявність опозиційних політичних партій, представники яких намагалися утворювати організації допомоги репресованим однопартійцям та їх родинам (у першу чергу, ініційований меншовиками Політичний Червоний Хрест) і голод 1921-1923 рр. Дозволяючи відкривати організації допомоги

\footnotetext{
12 Журба М.А. Етнонаціональні та міжнародні аспекти діяльності громадських об'єднань українського села (20-30 pр. ХХ ст.). Київ: Науковий світ, 2002. С. 77-78.

13 Там само. С. 79-80.

14 ГДА СБУ. Ф. 13. Оп. 1. Спр. 633. Арк. 3-4.

15 Там само. Арк. 5-6.
} 
у рамках окремих професій (Товариство взаємодопомоги залізничників Полтави, зареєстроване у 1922 р. і т.п.), влада пильно стежила за недопущенням консолідації представників альтернативних партій і рухів у подібних об'єднаннях. Не мали можливості працювати у легальному правовому полі меншовицькі організації взаємодопомоги репресованим і голодуючим в Одесі, Полтаві й інших містах України, сіоністські організації подібної спрямованості Одеси, Харкова, Києва і т.п. ${ }^{16}$

Тривале відомче листування супроводжувало вирішення питання юридичного статусу вказаних організацій. У лютому 1924 р. Наркомат соціального забезпечення СРСР запропонував не поширювати Постанову від 3 серпня 1922 р. на товариства засновані ремісниками, кустарями, торговцями, особами вільних професій для взаємної допомоги. Оскільки законодавство про соціальне страхування, державне забезпечення та селянську взаємодопомогу цих верств населення не стосувалося, то контроль за їхніми об’єднаннями Наркомат планував здійснювати зі своєї сторони. НКВС СРСР виступив проти, обгрунтовуючи необхідністю проявляти «особливу політичну обережність» стосовно «попутників» робітничого класу. Зрештою вирішено поширити на товариства допомоги й взаємодопомоги дію Постанови, а контроль за ними покласти на обидва наркомати ${ }^{17}$.

Жорстке регламентування дозвільної діяльності у першій половині 1920-х років не оминуло профспілкову сферу. Погодимось 3 думкою доктора права А. Білинського, що опартійнення всього організованого життя передбачалося самою системою диктатури пролетаріату. Зокрема, у профспілках цей процес наступив 3 початку 1920-х років. Формально вони були незалежною організацією, незалежною від держави. Стаття 152 Кодексу праці СРСР зазначала: «рофесійні спілки, зорганізовані на основах, визначених відповідними з'їздами тих організацій, реєструються тільки в їх міжспілкових організаціях у порядку, встановленому Всесоюзною Радою Професійних Спілок». На практиці вони були керовані партійними організаціями і тому реєстровані у партійному апараті. Згідно статті 153 Кодексу праці організація, яка не відповідає вимогам статті 152 Кодексу, не сміла і не сміє називатися профспілкою18.

Таким чином, у 1920-ті роки створена система взаємовідносин держави та громадських організацій базувалася на повній підлеглості їх до існуючої політичної доктрини та державному апарату. Політика підпорядкування громадських організацій більшовицькій владі проводилася з метою посилення впливу на суспільство та контролю за поведінкою навіть окремих його членів. Це нав'язувало об'єднанням завдання, форми, методи, характер їх діяльності. Внаслідок чого нівелювався головний принцип функціонування недержавних об’єднань - демократичність і самостійність. Правова залежність громадських організацій визначалась винятково дозвільним порядком створення та діяльності. Головною умовою для реєстрації постало зобов'язання діяти винятково під партійно-державним керівництвом, внаслідок чого в УСРР професійні, спортивні, наукові, молодіжні товариства перетворились на частину радянської політичної системи, граючи роль допоміжного механізму реалізації ідеолого-мобілізаційних заходів держави. Тим самим режим здійснював контроль за громадськими об’єднаннями, залучаючи їх представників до формування апарату та механізму діяльності радянської держави.

\footnotetext{
16 Державний архів Полтавської області. Ф. Р-1503. Оп. 1. Спр. 158. Арк. 35-36.

17 Ильина И.Н. Указ. раб. С. 38.

18 Білинський А.К. Вказ. пр. С. 27-28.
} 


\section{REFERENCES}

Bilynskyi, A. (1969). Hromadski orhanizatsii v SRSR [Public organizations in the USSR]. MiunkhenChikaho: Ukrainskyi Publitsystychno-Naukovyi Instytut [in Ukrainian].

Zhurba, M. (2002). Etnonatsionalni ta mizhnarodni aspekty diialnosti hromadskykh obednan ukrainskoho sela (20-30 rr. XX st.) [Ethnonational and international aspects of the activity of public associations of Ukrainian village (20-30 years of the XX century)]. Kyiv: Naukovyi svit [in Ukrainian].

Ilina, I. (2000). Obshhestvennye organizacii Rossii v 1920-e gody [Public organizations of Russia in the 1920s]. Moscow: Institut rossiiskoi istorii RAN [in Russian].

Kulchytskyi, S. (1996). Komunizm v Ukraini: pershe desiatyrichchia (1919-1928 rr.) [Communism in Ukraine: the first decade (1919-1928)]. Kyiv: Osnovy [in Ukrainian].

Chentsov, V. (2000). Politychni represii v Radianskii Ukraini v 20 -ti roky. [Political repressions in Soviet Ukraine in the 20's]. Ternopil: Zbruch [in Ukrainian].

\section{Ihor Nikolaev}

(Mykolayiv National University named after V. Sukhomlinsky, Mykolayiv, Ukraine)

ORCID: https://orcid.org/0000-0003-3001-9717

\section{Legislative Regulation and Control Mechanisms of the Public Associations of Ukraine Activities by Bilshovyk Authorities in the first half of the 1920s}

The key factors of establishing the Bilshovyk monopoly in the social and public sphere are analyzed. The role of state power and punitive institutions in establishing the absolute rule of Party members in the public sphere is clarified. As a result, the legal dependence of public organizations was determined by the solely licencing system for their creation and activities. The attention is focused on the policy of subordinating public organizations to the Bilshovyk authorities, which was aimed at strengthening the influence on the society and control of the behavior of even its individual members.

The mechanisms of legal regulation of the non-state social sector are shown. Their key factor was that almost all legislative and regulatory norms, including those related to regulating the Ukrainian SSR public associations activities, were based on the decisions of the central organs of Soviet power, initially the Russian Federation, and then the USSR. The automatic introduction of all-Russian norms into Ukrainian legislation was a conventional phenomenon. Thus, the monopoly of the ruling All-Russian Communist Party in all spheres of life of other republics and integrating socio-political organizations directly into the system of Soviet state power was legally secured.

It is proved that the main objective of the established legislative norms in the field of public associations functioning was the exercise by the ruling regime of control over their activities, and the involvement of their representatives in the formation of the Soviet state apparatus.

Keywords: public associations, totalitarian system, Soviet power, legislation, Ukrainian SSR 